\title{
Life Tables for Cystic Fibrosis
}

\author{
L. GEORGE and A. P. NORMAN \\ From The Hospital for Sick Children, Great Ormond Street, London
}

\begin{abstract}
George, L., and Norman, A. P. (1971). Archives of Disease in Childhood, 46, 139. Life tables for cystic fibrosis. Life tables for 128 children with cystic fibrosis without meconium ileus, and for $\mathbf{4 3}$ cases with meconium ileus, have been constructed for the five years starting in 1964. These are compared with similar tables constructed for the preceding 20 years and show narrowing of the gap between the life expectancy of those entered at birth and at diagnosis, and a very obvious improvement in survival rate. It is suggested that this is due to earlier diagnosis and treatment.
\end{abstract}

A life table is only a particular way of expressing the survival and death rates experienced by some particular population during a chosen period of time. Life tables are convenient methods of comparing the survival rates experienced at different times in the same place, and in different places at the same time. In this study life tables are used to compare the survival rates in children attending The Hospital for Sick Children with cystic fibrosis (CF) during the five years starting in January 1964, with the previous series published in 1966 from this hospital (Mantle and Norman, 1966). There are two methods of constructing a life table from a hospital series. (a) Entering the patient from birth, and (b) entering the patient from the age of definite diagnosis. The former will tend to underestimate, the latter to overestimate the true mortality (Mantle and Norman, 1966). The difference between these two tables depends on how soon after birth the diagnosis is made and treatment is begun.

\section{Source of Case Material}

A survey has been made of 224 children attending the hospital between 1 January 1964 and 31 December 1968. Out of these 216 were obtained from the Records Register, coded as suffering or possibly suffering from $\mathrm{CF}$ and/or meconium ileus. One case was obtained from the post-mortem register, and four cases which were not yet coded were added from the ward registers. Three cases were added from the records of private patients.

Out of these 172 were considered as CF not presenting as meconium ileus, and $\mathbf{5 2}$ as presenting with meconium ileus.

Received 3 August 1970
Cystic fibrosis not presenting as meconium ileus. Examination of the 172 case records revealed that only 128 could be entered in the construction of the life table. The remaining 44 fell into two groups: (a) 16 in whom diagnosis was not confirmed and who were not treated as CF, and (b) 28 seen at the hospital only to establish a definite diagnosis or for a second opinion and not followed up.

The diagnosis was accepted as in the previous study by Mantle and Norman (1966) on the basis of a suggestive clinical history, with at least one typical clinical manifestation and one laboratory confirmatory test, or of necropsy evidence where the histology was confirmatory. In the present study the sodium content of the sweat was estimated in the majority of cases. Out of 128 cases 45 were confirmed as CF elsewhere before they came to this hospital. In this group 40 were retested and 39 showed sweat sodium above $70 \mathrm{mEq} / 1$.; one showed sweat sodium to be $66 \mathrm{mEq} / 1$., but absent tryptic activity in the duodenal juice was considered to be confirmatory; and 5 were not retested. The remaining 83 cases were diagnosed initially at this hospital. Of these, one case had no sweat test or duodenal juice assay, but proteolytic enzymes were absent from the stools, together with typical clinical features. In one other case there was only a positive fingerprint test and no necropsy, but the clinical features were typical. Of the 83 cases, 72 had sweat sodium above $70 \mathrm{mEq} / \mathrm{l}$., estimated on a sweat sample of over $100 \mathrm{mg}$. 5 had sweat sodium above $70 \mathrm{mEq} / 1$., but the quantity was less than $100 \mathrm{mg}$ (4 of them had 50-100 mg and one had $40 \mathrm{mg}$ ). 3 had sweat sodium $60-68 \mathrm{mEq} / \mathrm{l}$., and 3 others had no sweat test.

There were 20 deaths in this group and 7 had no necropsy study. The remaining 13 were confirmed histologically.

Two life tables for CF not presenting as meconium ileus were constructed with the 128 cases in this group(a) entered at diagnosis, (b) entered at birth. In those cases diagnosed elsewhere before referral to this hospital 
TABLE I

Cystic Fibrosis not Presenting as Meconium Ileus

\begin{tabular}{|c|c|c|c|c|c|c|c|}
\hline \multicolumn{7}{|c|}{ Entered at Diagnosis } & \multirow{2}{*}{$\begin{array}{c}\text { Column A } \\
\text { Proportion of } \\
1000 \text { Alive } \\
\text { at Start } \\
\text { of Each } \\
\text { Period }\end{array}$} \\
\hline Age Group & $\begin{array}{l}\text { No. Present in } \\
\text { Series at Start } \\
\text { of Period }\end{array}$ & $\begin{array}{l}\text { No. Entering } \\
\text { Series During } \\
\text { Period }\end{array}$ & $\begin{array}{l}\text { No. in Period } \\
\text { Alive at End } \\
\text { of Survey } \\
\text { or Alive } \\
\text { at Transfer }\end{array}$ & $\begin{array}{l}\text { No. Dying } \\
\text { During } \\
\text { Period }\end{array}$ & $\begin{array}{c}\text { Effective } \\
\text { No. at } \\
\text { Risk }\end{array}$ & $\begin{array}{l}\text { Mortality per } \\
1000 \text { in } \\
\text { Period Shown }\end{array}$ & \\
\hline $\begin{array}{l}0 \\
1 \mathrm{mth} \\
3 \mathrm{mth} \\
6 \mathrm{mth} \\
9 \mathrm{mth} \\
1 \mathrm{yr} \\
2 \mathrm{yr} \\
3 \mathrm{yr} \\
4 \mathrm{yr} \\
5 \mathrm{yr} \\
6 \mathrm{yr} \\
7 \mathrm{yr} \\
8 \mathrm{yr} \\
9 \mathrm{yr} \\
10 \mathrm{yr} \\
11 \mathrm{yr} \\
12 \mathrm{yr} \\
13 \mathrm{yr} \\
14 \mathrm{yr} \\
15 \mathrm{yr} \\
16 \mathrm{yr}\end{array}$ & $\begin{array}{r}4 \\
17 \\
32 \\
39 \\
51 \\
63 \\
67 \\
68 \\
64 \\
53 \\
51 \\
44 \\
41 \\
36 \\
26 \\
13 \\
11 \\
9 \\
7 \\
6\end{array}$ & $\begin{array}{r}4 \\
13 \\
17 \\
9 \\
12 \\
18 \\
14 \\
13 \\
7 \\
6 \\
5 \\
4 \\
1 \\
2 \\
1 \\
1 \\
1\end{array}$ & $\begin{array}{r}1 \\
1 \\
6 \\
9 \\
10 \\
11 \\
16 \\
4 \\
10 \\
3 \\
6 \\
8 \\
13 \\
2 \\
2 \\
3 \\
2\end{array}$ & $\begin{array}{l}1 \\
1 \\
1 \\
2 \\
1 \\
3 \\
1 \\
1 \\
1 \\
2 \\
1 \\
1 \\
\\
1 \\
2\end{array}$ & $\begin{array}{l}2 \\
10 \cdot 5 \\
24 \cdot 5 \\
35 \cdot 5 \\
45 \\
57 \\
65 \\
67 \cdot 5 \\
66 \\
58 \cdot 5 \\
52 \\
47 \cdot 5 \\
42 \cdot 5 \\
38 \cdot 5 \\
31 \\
19 \cdot 5 \\
12 \\
10 \\
8 \\
6 \cdot 5 \\
4\end{array}$ & $\begin{array}{r}41 \\
27 \\
\\
14 \\
27 \\
15 \\
51 \\
17 \\
19 \\
20 \\
50 \\
37 \\
57 \\
\\
96 \\
265\end{array}$ & $\begin{array}{r}1000 \\
1000 \\
1000 \\
959 \\
932 \\
932 \\
932 \\
918 \\
891 \\
891 \\
876 \\
825 \\
808 \\
789 \\
769 \\
719 \\
682 \\
625 \\
625 \\
625 \\
529\end{array}$ \\
\hline
\end{tabular}

TABLE II

Cystic Fibrosis not Presenting as Meconium Ileus

\begin{tabular}{|c|c|c|c|c|c|c|c|}
\hline \multicolumn{7}{|c|}{ Entered at Birth } & \multirow{2}{*}{$\begin{array}{c}\text { Column A } \\
\text { Proportion of } \\
1000 \text { Alive } \\
\text { at Start of } \\
\text { Each Period }\end{array}$} \\
\hline Age Group & $\begin{array}{l}\text { No. Present in } \\
\text { Series at Start } \\
\text { of Period }\end{array}$ & $\begin{array}{l}\text { No. Entering } \\
\text { Series During } \\
\text { Period }\end{array}$ & $\begin{array}{l}\text { No. in Period } \\
\text { Alive at End } \\
\text { of Survey } \\
\text { or Alive } \\
\text { at Transfer }\end{array}$ & $\begin{array}{l}\text { No. Dying } \\
\text { During } \\
\text { Period }\end{array}$ & $\begin{array}{l}\text { Effective } \\
\text { No. at } \\
\text { Risk }\end{array}$ & $\begin{array}{l}\text { Mortality per } \\
1000 \text { in } \\
\text { Period Shown }\end{array}$ & \\
\hline $\begin{array}{l}0 \\
1 \mathrm{mth} \\
3 \mathrm{mth} \\
6 \mathrm{mth} \\
9 \mathrm{mth} \\
1 \mathrm{yr} \\
2 \mathrm{yr} \\
3 \mathrm{yr} \\
4 \mathrm{yr} \\
5 \mathrm{yr} \\
6 \mathrm{yr} \\
7 \mathrm{yr} \\
8 \mathrm{yr} \\
9 \mathrm{yr} \\
10 \mathrm{yr} \\
11 \mathrm{yr} \\
12 \mathrm{yr} \\
13 \mathrm{yr} \\
14 \mathrm{yr} \\
15 \mathrm{yr} \\
16 \mathrm{yr}\end{array}$ & $\begin{array}{r}128 \\
128 \\
126 \\
124 \\
124 \\
118 \\
108 \\
96 \\
85 \\
68 \\
61 \\
50 \\
46 \\
39 \\
29 \\
15 \\
12 \\
10 \\
7 \\
6\end{array}$ & 128 & $\begin{array}{r}1 \\
1 \\
6 \\
9 \\
10 \\
11 \\
16 \\
4 \\
10 \\
3 \\
6 \\
8 \\
13 \\
2 \\
2 \\
3 \\
2\end{array}$ & $\begin{array}{l}1 \\
1 \\
1 \\
1 \\
2 \\
1 \\
3 \\
1 \\
1 \\
1 \\
2 \\
1 \\
1 \\
\\
1 \\
2\end{array}$ & $\begin{array}{c}64 \\
128 \\
127 \\
125 \\
124 \\
121 \\
113 \\
102 \\
90 \cdot 5 \\
76 \cdot 5 \\
64 \cdot 5 \\
55 \cdot 5 \\
48 \\
42 \cdot 5 \\
34 \\
22 \\
13 \cdot 5 \\
11 \\
8 \cdot 5 \\
6 \cdot 5 \\
4\end{array}$ & $\begin{array}{r}8 \\
8 \\
\\
9 \\
19 \\
12 \\
44 \\
16 \\
18 \\
20 \\
50 \\
36 \\
56 \\
\\
\\
108 \\
298\end{array}$ & $\begin{array}{r}1000 \\
1000 \\
1000 \\
992 \\
984 \\
984 \\
984 \\
975 \\
956 \\
956 \\
944 \\
900 \\
884 \\
866 \\
846 \\
796 \\
760 \\
704 \\
704 \\
704 \\
596\end{array}$ \\
\hline
\end{tabular}


the date on which the child was first seen at this hospital was taken as the date of diagnosis. In those first diagnosed at this hospital the date of laboratory confirmation was taken as the date of diagnosis. In 3 cases treatment had been initiated before laboratory confirmation, and for these 3 the date of clinical diagnosis was accepted as the date of entry.

Cystic fibrosis presenting as meconium ileus. Examination of the 52 cases in this group revealed that only 43 could be entered in the construction of the life table. In 8 cases a wrong diagnosis was coded, and in one diagnosis was not confirmed.

Diagnosis was accepted on the basis of a typical history, confirmed by raised sweat sodium concentration, or by the histological findings on gut removed at operation, and in cases of death by the necropsy findings. There were 16 deaths altogether and out of these $3 \mathrm{had}$ no necropsy study. Among the 27 survivors the diagnosis was confirmed in 25 by sweat sodium estimation at a later date.

Two life tables were constructed with these 43 cases of meconium ileus: (a) entered at diagnosis-the date was taken as the date of primary operation, and in one case who had no operation, the date of laboratory confirmation; (b) entered at birth.

\section{Results and Discussion}

Life Tables I, II, III, and IV were derived according to the accepted methods of medical statistics (Hill, 1966).
TABLE III

Cystic Fibrosis not Presenting as Meconium Ileus

\begin{tabular}{c|c|c|c|c}
\hline \multirow{2}{*}{$\begin{array}{c}\text { Age } \\
(\mathrm{yr})\end{array}$} & \multicolumn{2}{|c|}{$\begin{array}{c}\text { Column I } \\
\text { Entered at Diagnosis }\end{array}$} & \multicolumn{2}{c}{$\begin{array}{c}\text { Column II } \\
\text { Entered at Birth }\end{array}$} \\
\cline { 2 - 3 } & $\begin{array}{c}1943-64 \\
\text { series }\end{array}$ & $\begin{array}{c}1964-68 \\
\text { series }\end{array}$ & $\begin{array}{c}1943-64 \\
\text { series }\end{array}$ & $\begin{array}{c}1964-68 \\
\text { series }\end{array}$ \\
\hline 0 & 1000 & 1000 & 1000 & 1000 \\
1 & 342 & 932 & 849 & 984 \\
5 & 189 & 891 & 641 & 956 \\
10 & 123 & 769 & 456 & 846 \\
15 & 74 & 625 & 276 & 704 \\
\hline
\end{tabular}

Cystic fibrosis not presenting as meconium ileus. In the present study the difference between the survival rates in Column A of Tables I (entered at diagnosis) and II (entered at birth) is small. The number of children above the age of 10 years is falling off, and so the effective number at risk is also going down; these children come from the earlier group in whom diagnosis was late, or therapy less effective. The apparently high mortality seen at 16 years of age is due to the very small number at risk in comparison with the number dying during the same period. The study was discontinued after this age group as most cases had been transferred to another hospital on the grounds of age, and the number remaining in the series was extremely small.

TABLE IV

Cystic Fibrosis Presenting as Meconium Ileus

\begin{tabular}{|c|c|c|c|c|c|c|c|}
\hline \multicolumn{7}{|c|}{ Entered at Diagnosis } & \multirow{2}{*}{$\begin{array}{c}\text { Column B } \\
\text { Proportion of } \\
1000 \text { Alive } \\
\text { at Start } \\
\text { of Each } \\
\text { Period }\end{array}$} \\
\hline Age Group & $\begin{array}{l}\text { No. Present in } \\
\text { Series at Start } \\
\text { of Period }\end{array}$ & $\begin{array}{l}\text { No. Entering } \\
\text { Series During } \\
\text { Period }\end{array}$ & $\begin{array}{l}\text { No. in Period } \\
\text { Alive at End } \\
\text { of Survey } \\
\text { or Alive } \\
\text { at Transfer }\end{array}$ & $\begin{array}{l}\text { No. Dying } \\
\text { During } \\
\text { Period }\end{array}$ & $\begin{array}{c}\text { Effective } \\
\text { No. at } \\
\text { Risk }\end{array}$ & $\begin{array}{c}\text { Mortality per } \\
1000 \\
\text { in Period } \\
\text { Shown }\end{array}$ & \\
\hline $\begin{array}{c}0 \\
1 \mathrm{dy} \\
2 \mathrm{dy} \\
3 \mathrm{dy} \\
4 \mathrm{dy} \\
5 \mathrm{dy} \\
6 \mathrm{dy} \\
7 \mathrm{dy} \\
14 \mathrm{dy} \\
1 \mathrm{mth} \\
3 \mathrm{mth} \\
6 \mathrm{mth} \\
9 \mathrm{mth} \\
1 \mathrm{yr} \\
2 \mathrm{yr} \\
3 \mathrm{yr} \\
4 \mathrm{yr} \\
5 \mathrm{yr} \\
6 \mathrm{yr} \\
7 \mathrm{yr} \\
8 \mathrm{yr} \\
9 \mathrm{yr} \\
10 \mathrm{yr}\end{array}$ & $\begin{array}{r}11 \\
22 \\
33 \\
33 \\
34 \\
34 \\
33 \\
31 \\
29 \\
26 \\
25 \\
21 \\
15 \\
16 \\
11 \\
5 \\
3 \\
2 \\
3 \\
2 \\
1\end{array}$ & $\begin{array}{r}11 \\
12 \\
11 \\
1 \\
1 \\
3 \\
1\end{array}$ & $\begin{array}{l}1 \\
2 \\
3 \\
6 \\
4 \\
5 \\
2 \\
1 \\
1 \\
1 \\
1\end{array}$ & $\begin{array}{l}1 \\
1 \\
4 \\
2 \\
2 \\
1 \\
1 \\
1 \\
1 \\
1 \\
1\end{array}$ & $\begin{array}{l}5 \cdot 5 \\
16 \cdot 5 \\
27 \cdot 5 \\
33 \\
33 \cdot 5 \\
34 \\
33 \cdot 5 \\
32 \\
30 \\
27 \cdot 5 \\
15 \cdot 5 \\
23 \\
18 \\
15 \cdot 5 \\
13 \cdot 5 \\
8 \\
4 \\
2 \cdot 5 \\
2 \cdot 5 \\
2 \cdot 5 \\
1 \cdot 5 \\
0 \cdot 5\end{array}$ & $\begin{array}{r}57 \\
29 \\
\\
109 \\
50 \\
50 \\
26 \\
27 \\
28 \\
35 \\
44 \\
68\end{array}$ & $\begin{array}{r}1000 \\
1000 \\
1000 \\
943 \\
943 \\
914 \\
914 \\
914 \\
805 \\
755 \\
705 \\
679 \\
652 \\
624 \\
589 \\
589 \\
545 \\
477 \\
477 \\
477 \\
477 \\
477 \\
477\end{array}$ \\
\hline
\end{tabular}


TABLE V

Cystic Fibrosis Presenting as Meconium Ileus

\begin{tabular}{|c|c|c|c|c|c|c|c|}
\hline \multicolumn{7}{|c|}{ Entered at Birth } & \multirow{2}{*}{$\begin{array}{c}\text { Column B } \\
\text { Proportion of } \\
1000 \text { Alive } \\
\text { at Start } \\
\text { of Each } \\
\text { Period }\end{array}$} \\
\hline Age Group & $\begin{array}{l}\text { No. Present in } \\
\text { Series at Start } \\
\text { of Period }\end{array}$ & $\begin{array}{l}\text { No. Entering } \\
\text { Series During } \\
\text { Period }\end{array}$ & $\begin{array}{l}\text { No. in Period } \\
\text { Alive at End } \\
\text { of Survey } \\
\text { or Alive } \\
\text { at Transfer }\end{array}$ & $\begin{array}{l}\text { No. Dying } \\
\text { During } \\
\text { Period }\end{array}$ & $\begin{array}{c}\text { Effective } \\
\text { No. at } \\
\text { Risk }\end{array}$ & $\begin{array}{l}\text { Mortality per } \\
1000 \text { in } \\
\text { Period Shown }\end{array}$ & \\
\hline $\begin{array}{c}0 \\
1 \mathrm{dy} \\
2 \mathrm{dy} \\
3 \mathrm{dy} \\
4 \mathrm{dy} \\
5 \mathrm{dy} \\
6 \mathrm{dy} \\
7 \mathrm{dy} \\
14 \mathrm{dy} \\
1 \mathrm{mth} \\
3 \mathrm{mth} \\
6 \mathrm{mth} \\
9 \mathrm{mth} \\
1 \mathrm{yr} \\
2 \mathrm{yr} \\
3 \mathrm{yr} \\
4 \mathrm{yr} \\
5 \mathrm{yr} \\
6 \mathrm{yr} \\
7 \mathrm{yr} \\
8 \mathrm{yr} \\
9 \mathrm{yr} \\
10 \mathrm{yr}\end{array}$ & $\begin{array}{r}43 \\
43 \\
42 \\
42 \\
41 \\
41 \\
41 \\
37 \\
35 \\
32 \\
29 \\
28 \\
24 \\
17 \\
17 \\
12 \\
6 \\
4 \\
3 \\
3 \\
2 \\
1\end{array}$ & 43 & $\begin{array}{l}1 \\
2 \\
3 \\
6 \\
4 \\
5 \\
2 \\
1 \\
1 \\
1 \\
1\end{array}$ & $\begin{array}{l}1 \\
1 \\
4 \\
2 \\
2 \\
1 \\
1 \\
1 \\
1 \\
1 \\
1\end{array}$ & $\begin{array}{l}21 \cdot 5 \\
43 \\
42 \cdot 5 \\
42 \\
41 \cdot 5 \\
41 \\
41 \\
39 \\
36 \\
33 \cdot 5 \\
30 \cdot 5 \\
28 \cdot 5 \\
26 \\
20 \cdot 5 \\
17 \\
14 \cdot 5 \\
9 \\
5 \\
3 \cdot 5 \\
3 \\
2 \cdot 5 \\
1 \cdot 5 \\
0 \cdot 5\end{array}$ & $\begin{array}{l}24 \\
24 \\
\\
98 \\
47 \\
48 \\
25 \\
26 \\
27 \\
33 \\
45 \\
67\end{array}$ & $\begin{array}{r}1000 \\
1000 \\
1000 \\
976 \\
976 \\
952 \\
952 \\
952 \\
854 \\
807 \\
759 \\
734 \\
708 \\
681 \\
648 \\
648 \\
603 \\
536 \\
536 \\
536 \\
536 \\
536 \\
536\end{array}$ \\
\hline
\end{tabular}

Table III shows the comparison with the previous study of 1943-64. The difference in the figures for the respective years in Columns I and II is large. Entered at diagnosis, at 1 year the survival rate is $34 \%$ in the previous study in comparison to $93 \%$ in the present one, and at 5 years $19 \%$ versus $89 \%$. This large difference is seen throughout and is probably due to the increased awareness of the nature of this illness among the medical profession, and the resultant earlier action.

Cystic fibrosis presenting as meconium ileus. Survival rates derived from the Tables show that the difference between Column $B$ in Tables IV and V is small. $48 \%$ are alive at 5 years, and there have been no deaths after the 5 -year age group. Hence the survival rate is maintained after this age group, though the effective number at risk falls off.

Table VI shows the comparison with the previous study. There is a significant difference in the survival rates. Surgical mortality, i.e. at one month after primary operation, derived from Column I in the present series, is about $25 \%$, whereas in the previous series it was about $67 \%$. At 1 year from Column I the survival rate is $62 \%$ in the present series and $10 \%$ in the previous one. The large difference is still seen at 5 years as $48 \%$ are surviving in the present series compared with $8 \%$ in the previous group.

TABLE VI

Cystic Fibrosis Presenting as Meconium Ileus

\begin{tabular}{|c|c|c|c|c|}
\hline \multirow{2}{*}{ Age } & \multicolumn{2}{|c|}{$\begin{array}{c}\text { Column I } \\
\text { Entered at Diagnosis }\end{array}$} & \multicolumn{2}{|c|}{$\begin{array}{c}\text { Column II } \\
\text { Entered at Birth }\end{array}$} \\
\hline & $\begin{array}{l}1943-64 \\
\text { series }\end{array}$ & $\begin{array}{c}1964-68 \\
\text { series }\end{array}$ & $\begin{array}{l}1943-64 \\
\text { series }\end{array}$ & $\begin{array}{c}1964-68 \\
\text { series }\end{array}$ \\
\hline $\begin{array}{l}0 \text { dy } \\
7 \text { dy } \\
14 \text { dy } \\
1 \mathrm{mth} \\
6 \mathrm{mth} \\
1 \mathrm{yr} \\
3 \mathrm{yr} \\
5 \mathrm{yr}\end{array}$ & $\begin{array}{r}1000 \\
609 \\
509 \\
327 \\
127 \\
102 \\
102 \\
82\end{array}$ & $\begin{array}{r}1000 \\
914 \\
805 \\
755 \\
679 \\
624 \\
589 \\
477\end{array}$ & $\begin{array}{r}1000 \\
754 \\
625 \\
407 \\
170 \\
143 \\
143 \\
126 \\
\end{array}$ & $\begin{array}{r}1000 \\
952 \\
854 \\
807 \\
734 \\
684 \\
648 \\
536 \\
\end{array}$ \\
\hline
\end{tabular}

\section{Conclusions}

The figures from the more recent life table reinforce the guarded optimism with which the prognosis in CF can be considered. They show the advantage to be obtained from early diagnosis and active treatment, and stress the need for a laboratory method for screening for $\mathrm{CF}$ in the first weeks of life. 
We thank Dr. David Mantle, Dr. C. O. Carter, and Professor A. C. Claireaux for their help; the consultant physicians and surgeons of The Hospital for Sick Children for permission to quote cases under their care; Mr. J. B. Ready and the staff in the Records Department for their great help; and Miss J. E. Robinson and Mrs. M. Breaks for secretarial assistance.
REFERENCES

Hill, A. B. (1966). Principles of Medical Statistics, 8th ed., Chapter XVIII, p. 220. Lancet, London.

Mantle, D. J., and Norman, A. P. (1966). Life table for cystic fibrosis. British Medical fournal, 2, 1238.

Correspondence to Dr. A. P. Norman, The Hospital for Sick Children, Great Ormond Street, London W.C.1. 